\title{
Diagnostic Value of Vaginal Discharge, Wet Mount and Vaginal pH - An Update on the Basics of Gynecologic Infectiology
}

\author{
Was Fluor, Nativpräparat und pH-Wert verraten - \\ Ein Update zu den Grundlagen der gynäkologischen Infektiologie
}

Authors

Affiliations
W. Frobenius ${ }^{1}$, C. Bogdan ${ }^{2}$

${ }^{1}$ Frauenklinik, Universitätsklinikum Erlangen, Erlangen

${ }^{2}$ Mikrobiologisches Institut, Universitätsklinikum Erlangen, Erlangen

\section{Key words}

- bacterial vaginosis

- vulvovaginal candidiasis

- trichomoniasis

- pelvic inflammatory disease

- vaginal $\mathrm{pH}$

\section{Schlüsselwörter}

- bakterielle Vaginose

- Vulvovaginalkandidose

- Trichomoniasis

- Pelvic inflammatory Disease

- vaginaler $\mathrm{pH}$-Wert

Deutschsprachige Zusatzinformationen online abrufbar unter: www.thieme-connect.de/ ejournals/toc/gebfra

\section{received $\quad 7.11 .2014$ \\ revised 22.12.2014 \\ accepted 9.1.2015}

Bibliography

DOI http://dx.doi.org/

10.1055/s-0035-1545909

Geburtsh Frauenheilk 2015; 75 :

355-366 @ Georg Thieme

Verlag KG Stuttgart · New York .

ISSN 0016-5751

\section{Correspondence}

\section{PD Dr. Wolfgang Frobenius}

Frauenklinik

Universitätsklinikum Erlangen

Universitätsstraße 21-23

91054 Erlangen

wolfgang.frobenius@

uk-erlangen.de

\section{Abstract \\ $\nabla$}

The majority of uncomplicated vulvovaginal complaints (e.g. bacterial vaginosis, vulvovaginal candidiasis, trichomoniasis) can be detected with uncomplicated basic infectiological tests and can usually be treated effectively without requiring further diagnostic procedures. Tests include measurement of vaginal $\mathrm{pH}$, preparation and assessment of wet mount slides prepared from vaginal or cervical discharge, and the correct clinical and microbiological classification of findings. In Germany, at least in recent years, this has not been sufficiently taught or practiced. As new regulations on specialist gynecologic training in Germany are currently being drawn up, this overview provides basic information on gynecologic infectiology and summarizes clinically relevant aspects of recent microbiological findings on the physiology and pathology of vaginal flora. The clinical signs and symptoms of aerobic vaginitis, the pathogenesis of which is still not completely understood, are also reviewed. Finally, the symptoms, indications and risk factors for pelvic inflammatory disease (PID) are presented. In contrast to the above-listed infections, PID requires immediate culture of the pathogen from samples (e.g. obtained by laparoscopy) with microbiological diagnostic procedures carried out by specialist laboratories. A schematic summary of all pathologies discussed here is presented.

\section{Introduction}

The diagnosis and treatment of vulvovaginal symptoms associated with genital infections accounts for a large proportion of gynecologic out-

\section{Zusammenfassung \\ $\nabla$}

Die überwiegende Zahl unkomplizierter vulvovaginaler Beschwerden (z. B. bakterielle Vaginose, Vulvovaginalkandidose, Trichomoniasis) lässt sich durch eine einfache, infektiologische Basisuntersuchung abklären und ohne weitergehende Diagnostik meist auch effektiv behandeln. Zu dieser Untersuchung gehören die Messung des vaginalen pH-Wertes, die Anfertigung und Beurteilung eines Nativpräparats aus vaginalem bzw. zervikalem Fluor sowie die korrekte Einordnung der erhobenen Befunde in das klinische Bild und den mikrobiologischen Kontext. Zumindest in Deutschland wird dies seit Jahren zu wenig gelehrt und praktiziert. Die vorliegende Übersicht vermittelt deshalb auch im Hinblick auf die kommende neue Weiterbildungsordnung grundlegende Kenntnisse dazu und fasst gleichzeitig den klinisch relevanten Teil der aktuellen mikrobiologischen Erkenntnisse zur Physiologie und Pathologie der Vaginalflora zusammen. Ferner wird das pathogenetisch nach wie vor unvollständig verstandene Krankheitsbild der aeroben Vaginitis diskutiert. Letztlich werden auch Symptome, Zeichen und Risikofaktoren einer Entzündung des kleinen Beckens („Pelvic Inflammatory Disease“, PID) vorgestellt, da diese Erkrankung im Gegensatz zu den obengenannten einen unverzüglichen kulturellen und/oder molekularen Erregernachweis durch entsprechende Materialgewinnung (z.B. mittels Laparoskopie) und mikrobiologische Labordiagnostik erfordert. Für alle dargestellten Krankheitsbilder werden Schemata zum therapeutischen Vorgehen präsentiert.

patient consultations. Infectiological diagnostics and treatment play a not unimportant role in hospitals, although the focus there is primarily on infections of the cervix (cervicitis), endometrium (endometritis), fallopian tubes and ovaries (oo- 
phoritis, salpingitis or adnexitis) as well as - in the worst case inflammations of the entire minor pelvis including generalized peritonitis and sepsis. The latter pathologies are grouped together under the term pelvic inflammatory disease (PID).

Despite its enormous practical importance, infectiological training in gynecology still leaves much to be desired [1]. Attempts to detect the underlying causes of symptoms may be carried out on a "trial and error" basis, resulting in unnecessary or inadequate microbiologic diagnostic investigations and antibiotic treatment which may not be indicated or may be insufficient or - in the worst case - have adverse consequences for patients [2].

Experience has shown that the biggest problem lies in the basic infectiological diagnostic procedures. For various reasons, specialist knowledge of how to prepare and assess wet mount slides for microscopic investigation of vaginal discharge is the exception rather than the rule in outpatient clinics or hospitals. In contrast to the United States for example where regulations require wet mount proficiency testing, gynecologists in Germany do not currently need to prove their specialist knowledge in this area. The subject will only now become part of mandatory specialist training in gynecology. In July 2014 the Professional Society for Infections and Infection Immunology (AGII) in Germany drew up and published the content requirements for this subject area [3].

This is an extremely welcome development, not least because the overwhelming number of uncomplicated vulvovaginal symptoms can already be diagnosed using basic diagnostic procedures; the diagnosis of bacterial vaginosis (BV), vulvovaginal candidiasis and the now rarely occurring (in Germany) trichomoniasis is usually fairly straightforward based on the patient's medical history, clinical examination with measurement of vaginal $\mathrm{pH}$, whiff/KOH test and evaluation of wet mount slides. All of these methods are usually also sufficient to differentiate between normal vaginal findings and bacterial vaginitis not caused by protozoa or fungal infection (for example aerobic vaginitis) with a relatively high degree of accuracy. Basic diagnostic procedures can also be used in the often difficult differential diagnosis of lower abdominal pain to exclude PID with a high level of negative predictive certainty. The emphasis of this article is therefore on basic diagnostic procedures that can be carried in the practice of a registered doctor or in hospital at limited cost. In addition to the physiology and pathology of the vaginal flora in women of reproductive age, details of the aforementioned diseases will be discussed as they are the causes of vulvovaginal symptoms in up to $90 \%$ of cases $[4,5]$.

It must be emphasized that a detailed investigation by a medicalmicrobiological testing laboratory must carried out for all serious (e.g. ascending infections, salpingitis, adnexitis) or life-threatening conditions (e.g. peritonitis, sepsis) if there is a suspicion that unusual pathogens may be present (e.g. actinomycetes in patients with intrauterine devices [IUD]), when infections are recurrent or chronically persistent, and - with the exception of trichomoniasis - for all sexually transmitted diseases, as in such cases it will be necessary to culture the pathogens and/or carry out molecular identification of the pathogens and determine their sensitivity to antibiotics. The principles of microbiologicalinfectiological diagnostic procedures for genital infections, in particular the use of stepwise diagnostic procedures and the preconditions which must be observed prior to analysis regarding the collection, storage and transport of specimens together with information on pointless examination methods, have been listed and described in the microbiological-infectiological quality stan- dards (MiQ) of the German Society for Hygiene and Microbiology (DGHM) [6,7], and even a summary would far exceed the scope of the discussion possible here.

\section{Physiology and Pathology of Vaginal Flora}

$\nabla$

Important aspects of the knowledge of the physiology and pathology of vaginal flora, which for around a century was based on examinations of cultured specimens, are currently changing. According to a recent overview by Lamont et al. [8], molecular techniques used to supplement the knowledge obtained over the past 100 years have shown that

- the diversity of organisms in the vaginal milieu is much greater than was initially thought,

- the role of Lactobacillus requires a more nuanced assessment,

- the range of what is "normal" is broader than was thought, and

- bacterial vaginosis should probably be understood more as a symptom than as a uniform clinical picture.

The principle that Lactobacillus predominates in the vaginal flora of healthy women of reproductive age still generally applies. Lactobacillus organisms metabolize the estrogen-dependent glycogen stored in the squamous epithelium to lactic acid, which contributes to create a vaginal $\mathrm{pH}$ equal to or less than 4.5. Acidic $\mathrm{pH}$ but also $\mathrm{H}_{2} \mathrm{O}_{2}$ production by many Lactobacillus species together with a number of other factors are responsible for ensuring that the numbers of other bacteria also found in the "commensal flora" of the vagina remain below a critical threshold.

However, an absence of Lactobacillus does not inevitably result in illness; molecular biological investigations have identified other bacteria which produce lactic acid and thus contribute to maintaining a normal vaginal milieu (e.g. Atopobium vaginae, Megasphaera and Leptotrichia) [9]. Nor is cultured proof of a limited number of facultative pathogenic bacteria (e.g. Gardnerella vaginalis, E. coli, Pseudomonas spp., Group B Streptococcus, or Peptostreptococci) necessarily an indication for treatment [8]. Exceptions to the rule are specific pathogenic organisms such as the pathogens of sexually transmitted diseases or, in special cases, Group A Streptococcus (S. pyogenes).

According to recent studies, colonization with two or more Lactobacillus species is common in healthy women with Lactobacillus flora. Colonization usually consists of L. crispatus and L. iners or less commonly L. jensenii and L. gasseri. The individual woman's genetic and geographic origins will influence the type of colonization. Investigations into this issue have focused on the use of probiotics to treat bacterial vaginosis. Some of the data obtained appears promising but the overall data is not yet sufficient [10, 11].

The most common disorder of vaginal flora is bacterial vaginosis (BV). BV is not an infectious process in the classic sense: typical inflammatory characteristics such as the presence of increased leukocytes in vaginal discharge are absent. Microbiological characteristics include quantitative and qualitative decline in Lactobacillus colonization together with an increase by a factor of 1000 of anaerobic bacteria detectable by culture associated with bacterial vaginosis such as Gardnerella vaginalis, Mobiluncus spp., Leptotrichia/Sneathia, Megasphaera and Mycoplasma hominis [8].

The pathogenesis of BV is still unclear as is the answer to the question whether it is a sexually transmitted disease. A biofilm adhering the vaginal wall of affected women is commonly the cause of recurrence after treatment. The hypothesis whereby BV 
is more likely to be a syndrome is the result of molecular investigations which may, at one point in the not too distant future, replace the classic diagnostic procedures used to diagnose imbalances of vaginal flora and lead to a more differentiated treatment [8]. The symptoms of BV will be discussed in more detail below. In contrast to BV vulvovaginal candidiasis is a condition where local classic signs of inflammation (redness, edema) are present as a consequence of invasion of the epithelium by the pathogen. Candidiasis is not generally associated with elevated vaginal $\mathrm{pH}$ levels. On the contrary: it is rare for a fungal infection to be present in combination with vaginosis. Asymptomatic colonization of the vagina with Candida species is relatively common and does not require treatment nor does colonization with commensal bacteria in women who experience no symptoms.

Classic local signs of inflammation also occur with trichomoniasis and aerobic vaginitis. Leukocytosis on wet mount is usually also present.

\section{Infectiological Examination}

\section{$\nabla$}

\section{Medical history}

Patients with vulvovaginal symptoms usually complain of malodorous vaginal discharge. Additional symptoms can include itching, a burning sensation, spotting and dyspareunia. Lower abdominal pain or fever in association with these symptoms can be an indication that the infection is already ascending.

Taking the patient's sexual history is a particularly important aspect of the infectiological examination. It is necessary not just to ask about the type of partnerships but also about changes in partners and sexual practices which could promote infections. Additional important points to elucidate are previous diseases which may be relevant, prior procedures affecting the genital area (e.g. placement of an IUD, curettage, cervical laser surgery or hysterectomy) and the patient's menstruation history (e.g. treatmentresistant bleeding disorders as a potential symptom of endometritis).

\section{Clinical examination \\ Inspection}

Any inspection of the external genitals and perianal region must first look for conspicuous skin changes. These include, in the first instance, signs such as inflammation, ulceration, scratch marks and tumoral changes which can be very minute (e.g. very small condylomata acuminata). There is usually no vaginal discharge on the vulva. If a discharge is present, then it must be categorized based on the patient's medical history, the extent of the discharge, its consistency and smell. A microbiological examination is always recommended if there are indications of external vulvitis [6]. The most common cause is Candida albicans, followed by Staphylococcus aureus and Streptococcus pyogenes. Lesions combined with swollen lymph nodes of the groin may be due to primary genital herpes. The inspection is only complete after the introitus has been examined by spreading the labia.

\section{Adjusting the speculum}

When adjusting the speculum and during subsequent examination it is important to follow a previously defined sequence of events. This should prevent falsification of $\mathrm{pH}$ results (for example, through the use of ultrasound gel) or interference with wet mount (for example, due to iatrogenic bleeding). Each step, from the introduction of the speculum, the visualization of the cervix

\section{Table 1 Wet mount and "whiff" test.}

\begin{tabular}{|c|c|}
\hline $\begin{array}{l}\text { Unstained } \\
\text { wet mount: }\end{array}$ & $\begin{array}{l}1 \text { drop pf } 0.9 \% \mathrm{NaCl} \text { is placed on a slide; a spatula is used to } \\
\text { take a sample of the discharge from the vaginal vault; the } \\
\text { sample is carefully mixed with the } 0.9 \% \mathrm{NaCl} \text { on the glass } \\
\text { slide; this is then carefully covered with a cover slide (avoid } \\
\text { "smearing" and trapped air). }\end{array}$ \\
\hline $\begin{array}{l}\text { Stained } \\
\text { wet mount: }\end{array}$ & $\begin{array}{l}\text { Instead of the unstained } \mathrm{NaCl} \text { solution, place } 1 \text { drop of } 0.9 \% \\
\mathrm{NaCl} \text { stained with methylene blue on the slide. } \\
\text { Preparation of the solution: draw up } 0.2 \mathrm{ml} \text { of } 0.5 \% \text { meth- } \\
\text { ylene blue and } 1.8 \mathrm{ml} \text { of } 0.9 \% \mathrm{NaCl} \text { in a } 2 \mathrm{ml} \text { syringe. } \\
\text { The solution can be used for several days after preparation } \\
\text { if the syringe is kept closed. }\end{array}$ \\
\hline Whiff test: & $\begin{array}{l}\text { A second discharge sample (prepared in the same way as } \\
\text { the unstained wet mount) is incubated with one drop of } \\
10 \% \mathrm{KOH} \text { solution (from the pharmacy) without a cover } \\
\text { slip. The fishy amine odor which this could trigger is ex- } \\
\text { tremely volatile. A sniff test should therefore be done } \\
\text { immediately. }\end{array}$ \\
\hline
\end{tabular}

Note: microscopic examination of wet mount should be done within 10 minutes of preparation; if there is a suspicion of trichomonads use unstained wet mount.

to the removal of the speculum, must always be carried out accompanied by careful examination of the vagina for inflammatory changes, a search for ulcers or structures suspicious for neoplasia, and assessment of vaginal and cervical discharge.

Once the cervix has been visualized, the second step should consist of measurement of $\mathrm{pH}$ level using a test strip placed against the vaginal wall in the middle third of the vagina. The strip should be fully moistened. It is important to avoid cervical mucous because this will falsify the test result. The most suitable test strips - because they can be easily read - are test strips which measure a very limited spectrum (e.g. pH 4-7).

In the next step of the examination, a plastic or metal spatula is used to obtain a sample of the discharge from the vaginal vault for wet mount; the sample is then placed on a prepared glass slide for microscopic examination and covered with a cover slip. Wet mount should be examined within 10 minutes of preparation as otherwise changes to the structures will occur.

If a patient only complains of the occurrence of an unpleasant "fishy" smell (amine odor) under certain conditions (sex, menstruation) or if other reasons indicate a suspicion of bacterial vaginosis, a $\mathrm{KOH}$ test (whiff test) should be carried out for verification ( Table 1 ).

If a microbiological examination is indicated, then swabs should be taken after creating wet mount(s). The site where the swab is taken depends on what is being investigated (vaginitis, cervicitis):

- swabs for bacterial cultures are taken from the cervical surface around the outer cervical os, from the cervical canal or from the vagina

- swabs for a molecular diagnosis of chlamydia are taken from the cervical canal, and

- swabs for fungal culture are taken from the affected site on the vulva and in the vagina

A suitable transport medium selected in consultation with the laboratory doing the diagnosis is necessary to ensure that microbiological diagnosis with Gram stain, culture and/or PCR is adequate. An intracervical swab for chlamydia must include cellular material (insert the swab approx. $1 \mathrm{~cm}$, turn it carefully). Microbiological examination is categorically indicated when any of the following are present: 
- purulent cervicitis (swab from the cervical canal)

- BV plus an additional factor (e.g. lower abdominal pain)

- suspicion of mycosis and negative wet mount

- chronic recurrent mycosis

- abrasion material from the uterus shows signs of inflammation on histology

- wet mount with more leukocytes than epithelia or $>25$ leukocytes in the cervical secretion (at a magnification of $400 \times$ )

\section{Palpation}

Palpation is done in accordance with standard procedure. The most relevant aspect from an infectiological standpoint is whether cervical motion tenderness is present. If there is a suspicion of ascending infection with involvement of the adnexa, a tumor may be palpated. Examination must include the lymph nodes in the groin, which are usually swollen if certain infections are present (e.g. herpes, syphilis, Hodgkin's lymphoma).

\section{Transvaginal ultrasound}

Ultrasound is usually done at the end of the clinical examination. No pathological findings are expected if disease is limited to the vulva and vagina. If there is a suspicion of PID, imaging may show thickened, fluid-filled tubes, the "cogwheel sign" in the crosssection of the fallopian tubes or even an inflammatory tumor in the region of the adnexa, any of which will contribute to the final diagnosis. However, the presence of free fluid and increased vascularization on Doppler are not specific [13].

\section{Evaluation of wet mount}

With a bit of practice it should be possible to make the following diagnoses based on wet mount:

- unremarkable microscopic findings (normal epithelia, polymorphous rod-shaped bacteria, only isolated leukocytes, no indications for candidiasis),

- suspicion of bacterial vaginosis (more than 20\% "clue cells" present, absence of lactobacilli, mixed bacterial flora with rods and cocci, but no increase in the number of leukocytes),

- inflammation (more leukocytes than epithelia or > 25 leukocytes at a magnification of $400 \mathrm{x}$, poss. indication of candidiasis or infection with trichomonads).

- Fig. 1 provides some pointers for the evaluation of wet mount. Further information can be obtained online using the keywords "wet mount proficiency" or "wet prep". Past "proficiency tests" are available online and can be used for training. The textbook and atlas "Infektionen in Gynäkologie und Geburtshilfe" [14] is recommended for German evaluators. Another recently published book for German readers with numerous illustrations is "Phasenkontrast-Mikroskopie in der Frauenarztpraxis" [15].

After performing the basic examination described above, the results in the overwhelming majority of cases will allow the examiner to differentiate between normal findings, bacterial vaginosis, and infection. Under certain circumstances it may already be possible to detect the cause of infection, for example when Candida albicans or Trichomonas vaginalis are present. The diagnostic procedures for the evaluation of discharge proposed in the Microbiological Quality Standards (MiQs) as an alternative or in addition to wet mount with Gram stain and assessment based on the Nugent score have a higher sensitivity and specificity but, for reasons of practicality, when gynecological examination is done in an outpatient clinic such procedures should be reserved for special cases $[6,7]$.

\section{Suspicion of Ascending Infection (PID)}

$\nabla$

Bacterial vaginosis, vaginitis or cervicitis diagnosed using any of the methods described above together with lower abdominal pain, cervical motion tenderness or tenderness of the uterus and/or of the adnexa on pressure suggest acute PID. Conversely, PID is unlikely if purulent cervical discharge is not visible and leukocytosis is not detected on wet mount in a patient with lower abdominal pain of an indeterminate nature. In these cases it will be necessary to look for another cause for the symptoms $[16,18]$ (see below).

The risk factors for PID correspond to those which also apply to the acquisition of sexually transmitted diseases (STD). These include age younger than 25 years; first intercourse at a young age; new sexual partner or frequent change of partners; no use of contraceptive barrier methods. In addition to BV and cervical ectopia, other potentially contributing factors include intercourse during menstruation and new placement of an IUD (within a period of 21 days to 6 weeks) as well as a prior history of PID.

Other indications for PID are systemic signs of inflammation (fever $>38^{\circ} \mathrm{C}$; elevated $\mathrm{CRP}$ and higher numbers of leukocytes in blood) as well as the findings on transvaginal ultrasonography mentioned above. Overall, PID has proved to be something of a chameleon in terms of presenting symptoms: presentation as acute abdomen with the full range of all signs of inflammation is as likely as isolated mild symptoms. A not inconsiderable number of cases of PID are even completely asymptomatic and are only detected accidentally because of the long-term consequences for example during diagnostic procedures for infertility.

\section{Liberal indications for laparoscopy}

Depending on the symptoms, numerous other diseases also need to be considered in the differential diagnosis. Potential gynecological conditions include symptomatic adnexal masses (ovarian cyst or tumor, twisted appendage), complications of pregnancy (ectopic pregnancy, incipient miscarriage), dysmenorrhea and endometriosis. Other potential surgical or medical conditions include appendicitis, cholecystitis, gastroenteritis, chronic inflammatory bowel disease or obstipation. Urological diseases which present with pertinent symptoms include urethritis, cystitis, pyelonephritis and nephrolithiasis.

The general consensus is now that there is no gold standard for the diagnosis of PID. Laparoscopy has its limitations: a less experienced investigator may miss the subtle signs of salpingitis; endometritis can only be verified histologically. Nevertheless, under certain circumstances the indications for laparoscopy should be interpreted liberally, particularly in younger women, because PID which is not treated or treated inadequately can have serious consequences for fertility. Only gynecologic laparoscopy (pelviscopy) will allow careful inspection of the site, permit intraabdominal detection of the pathogen (PCR, culture, resistance testing) and allow surgical procedures such as tubal opening and removal of blockage in sactosalpinx to be carried out during the same session [17]. Depending on the findings, samples for microbiological examination must be taken from the fimbriae, from the Douglas pouch or from an abscess if present, placed in a suitable medium and sent to the laboratory within two hours, where they should be investigated immediately. Cell-poor fluid from the Douglas pouch cannot be used to diagnose adnexitis or salpingitis [6]. If laparoscopy is negative in a woman with tenderness of the internal genital organs on palpation, endometrial 


\section{How to identify important structures}

The important thing when evaluating wet mount is to clearly identify the most important structures and not get confused. The comparison of the relative sizes of various structures with that of the standard structure "vaginal epithelial cell with nucleus" is a crucial identification tool.

\section{Normal vaginal epithelium, lactobacilli:}

Normal squamous epithelial cells (1) are the standard structures on wet mount: Under the influence of sexual hormones they are large, clearly defined and rich in cytoplasm. Their nuclei can also be clearly discerned. Epithelial cells must always be identified first. The image also shows a number of polymorphous rod-shaped bacteria which correspond to lactobacilli.

a Normal wet mount with epithelial cells and lactobacilli stained with $0.1 \%$ methylene blue.

\section{Normal epithelium, yeast, leukocytes (granulocytes):}

Blastospores (1) are the smallest important structures on wet mount (half the size of the nucleus of an epithelial cell). They can be either round or oval shaped. They should only be identified as blastospores if they are present in groups.

Pseudohyphae (2) in Candida albicans develop from blastospores. The walls of pseudohyphae are parallel, their structures delicate.

Granulocytes (3) are approximately the same size as the nuclei of epithelial cells, but the nuclei of granulocytes are segmented. This allows them to be differentiated from "naked" epithelial cell nuclei after cytolysis.

b Wet mount with epithelial cells, blastospores, pseudohyphae and granulocytes.

\section{Size comparisons of important structures}

- Trichomonad: $\leq 25 \mu \mathrm{m}$

- Nucleus of a squamous epithelial cell: $15 \mu \mathrm{m}$

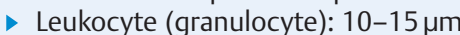

- Erythrocyte: 6-8 $\mu \mathrm{m}$

- Blastospore: $5-7 \mu \mathrm{m}$
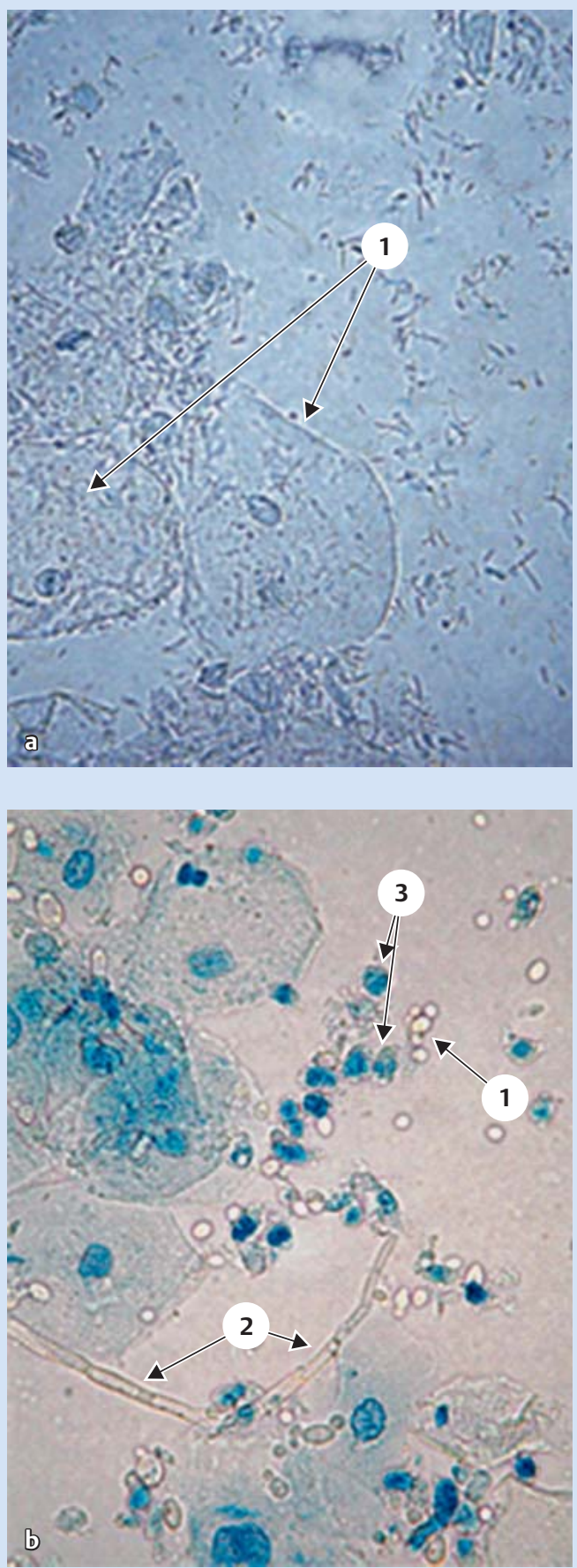

Continued next page 


\section{Clue cells, normal epithelium:}

Squamous epithelial cells change to clue cells (1) following extensive bacterial colonization and their edges cannot be defined clearly. The nuclei can often only be detected after careful adjustment of the micrometer screw. Normal epithelium is clearly defined (2).

c Clue cells (1), normal epithelium (2).

\section{Erythrocytes, granulocytes:}

Erythrocyte sizes (1) compared to granulocytes (2) and blastospores (3); normal epithelial cells are also present. Erythrocytes rapidly change their shape: on fresh wet mount they are round, after five to ten minutes they begin to show indentations along their edges. An indentation (concavity) is often present in the middle of the cell.

d Size of erythrocytes (1) compared to granulocytes (2) and blastospores (3); epithelial cells (4).

\section{Trichomonads}

Trichomonads (1) are flagellated protozoan parasites; in their motile form they are easily identified on unstained wet mount by their convulsive movements. They die off very quickly outside their milieu and change their shape. Trichomoniasis should only be diagnosed microscopically if motile organisms can be identified.

\section{e Trichomonad which has become difficult to} identify (1), leukocytes (2), epithelial cells (3).
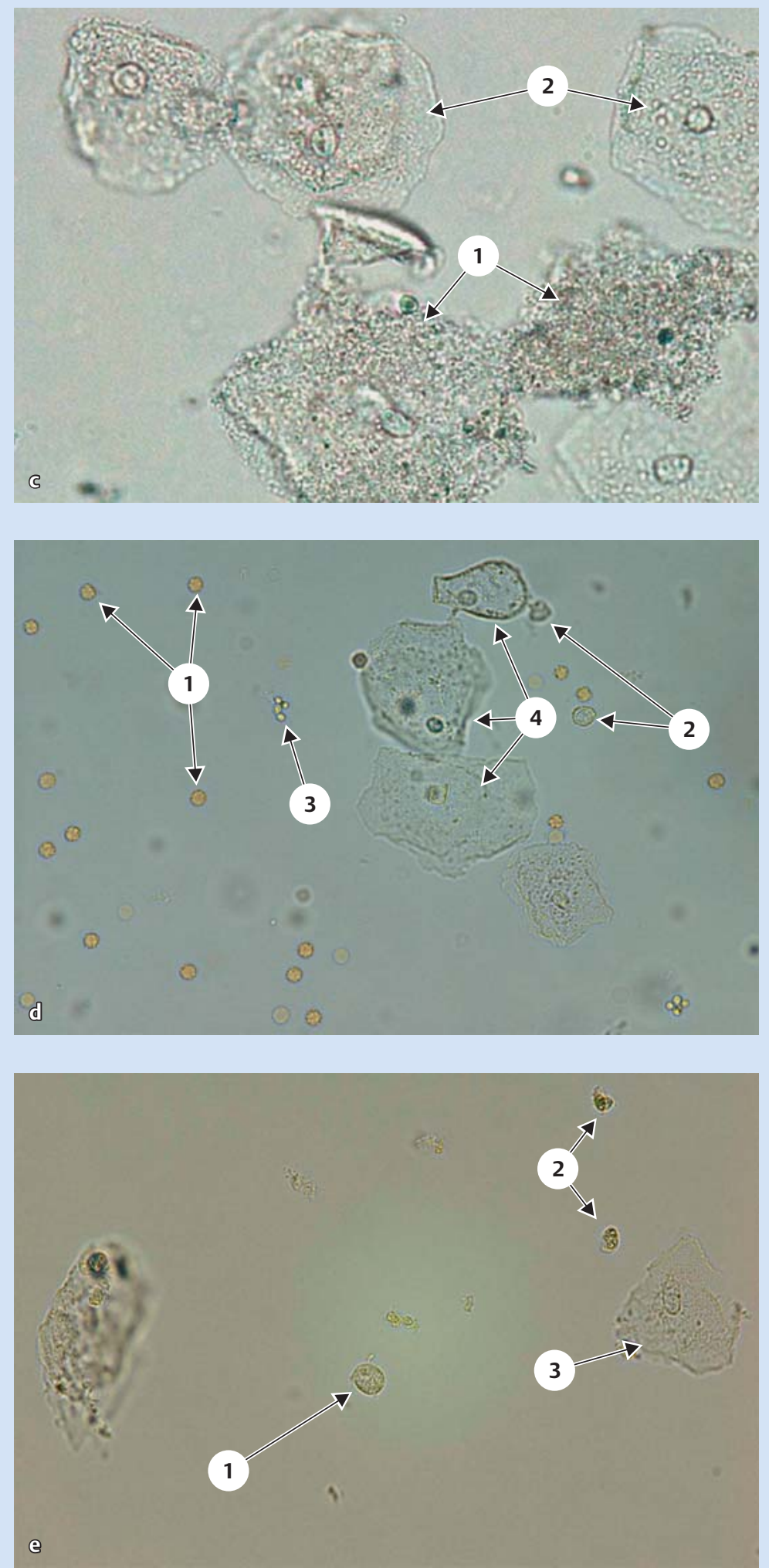

Fig. 1 a to $\mathbf{e}$ Essential findings on wet mount. Sources: $\mathbf{a}$ and $\mathbf{b}$ from: Petersen EE. Infektionen in Gynäkologie und Geburtshilfe. Lehrbuch und Atlas. 5th revised and expanded edition. Stuttgart: Thieme; 2011: p. 82 (Fig. 6.30) and p. 94 (Fig. 7.5) [14]. $\mathbf{c}$ to e from "Internal Proficiency Program for Wet Mount Microscopy" from the Department of Community Health of the State of Michigan (USA) [39]. 
Table 2 Combination therapies for PID (modified and based on $[16,17,40]$ ).

\begin{tabular}{|c|c|c|}
\hline Combinations of active ingredients & Dose & Length of treatment \\
\hline \multicolumn{3}{|l|}{ Mild to moderate form } \\
\hline $\begin{array}{l}\text { 1. Ceftriaxone plus } \\
\text { doxycycline }\end{array}$ & $\begin{array}{l}250 \mathrm{mg} \text { i. m. } \\
2 \times 100 \mathrm{mg} / \text { day orally }\end{array}$ & $\begin{array}{l}\text { single dose } \\
14 \text { days }\end{array}$ \\
\hline \multicolumn{3}{|l|}{ Alternatively } \\
\hline $\begin{array}{l}\text { 2. Amoxicillin/clavulanic acid plus } \\
\text { doxycycline }\end{array}$ & $\begin{array}{l}2-3 \times 875 \mathrm{mg} / 125 \mathrm{mg} \text { per day orally } \\
2 \times 100 \mathrm{mg} / \text { day orally }\end{array}$ & * 14 days \\
\hline \multicolumn{3}{|l|}{ Alternatively } \\
\hline 3. Ofloxacin plus & $2 \times 400 \mathrm{mg}$ per day orally & * \\
\hline metronidazole & $2 \times 500 \mathrm{mg}$ per day orally & 14 days \\
\hline \multicolumn{3}{|c|}{$\begin{array}{l}\text { The first two regimens can be additionally combined with metronidazole to ensure effectiveness against anaerobes (combination } 1 \text { ) or increase effectiveness even } \\
\text { further (combination 2). These regimens also treat potentially present BV. The use of azithromycin (off label) is a possible alternative to doxycycline and ofloxacin, both } \\
\text { of which are contraindicated in pregnancy; suggested azithromycin dosage: } 1 \times 1 \mathrm{~g} \text { per week [33]. }\end{array}$} \\
\hline \multicolumn{3}{|l|}{ Severe form } \\
\hline 1. Ceftriaxone plus & $1 \times 2,0 \mathrm{~g} /$ day & * \\
\hline metronidazole plus & $2 \times 500 \mathrm{mg} /$ day (i.v. or orally) & * \\
\hline doxycycline & $2 \times 100 \mathrm{mg} /$ day, orally where possible & 14 days \\
\hline \multicolumn{3}{|l|}{ Alternatively } \\
\hline 2. Piperacillin/tazobactam plus & $4.0 \mathrm{~g} / 0.5 \mathrm{~g}$ every 8 hours i. v. & * \\
\hline doxycycline & $2 \times 100 \mathrm{mg} /$ day, orally where possible & At least 14 days \\
\hline \multicolumn{3}{|l|}{ Alternatively } \\
\hline 3. Meropenem & 500 mg/every 8 hours i.v. & * \\
\hline
\end{tabular}

Azithromycin can also be used as an alternative to doxycycline (pregnancy!) to treat severe PID.

* On the length of treatment: data on the length of treatment required when administering antibiotic therapies is poor and inconsistent. With the exception of single doses and the use of doxycycline to treat chlamydia (at least 14 days), the length of treatment should depend on the clinical condition (rule of thumb: intravenous antibiotic treatment should be discontinued at the earliest 24 hours after significant clinical improvement; length of treatment should be at least 7 days, usually not more than 14 days).

biopsy or "protected" uterine swab of the uterus should be considered $[6,16]$.

The serious consequences of undetected or inadequately treated PID have led to the recommendation that, when in doubt, broadspectrum antibiotic therapy should be initiated. Treatment regimens must cover the most common pathogens (chlamydia, gonococcal infection, transient microorganisms from the vaginal flora and bacterial vaginosis). Treatment must therefore initially offer empiric broad-spectrum coverage of likely pathogens; however the necessary impact on anaerobes is still discussed controversially. The extent and severity of symptoms must also be considered because the clinical picture will determine whether the patient should be treated on an inpatient or an outpatient basis. Oral outpatient treatment is the standard therapy to treat women with mild to moderate PID. In the European and US guidelines for the management of PID $[16,18]$, indications for intravenous inpatient therapy to treat severe PID are:

- severe symptoms and signs (high fever, nausea, vomiting, strong pain)

- complicated clinical picture with abscess formation

- potential need for surgical intervention (diagnostic or therapeutic)

- pregnancy.

A dual or even triple antibiotic regimen is indicated to treat PID. Intravenous therapy to treat severe PID should be continued for at least 24 hours after significant improvement of symptoms, after which treatment can switch to oral therapy. Antibiotic deescalation should be implemented as soon as possible once the pathogen and the antibiogram are known ( Table 2 ).

The European and the US guidelines recommend a combination therapy of gentamicin and clindamycin but these authors are of the opinion that, for various reasons, this recommendation should be scrutinized very critically and has therefore not included it in the table. Objections to using a combination of genta- micin and clindamycin include the control of serum levels required when using gentamicin, the not insignificant side-effects associated with both substances, particularly after long-term intake, and the limited spectrum of efficacy (ineffectiveness of gentamicin against anaerobes, ineffectiveness of clindamycin against Gram-negative bacteria, lack of synergy between the two substances). The superiority of gentamicin/clindamycin compared to other regimens, all of which achieve very similar outcomes, has never been proven.

\section{Bacterial Vaginosis \\ $\nabla$}

\section{Prevalence}

As previously mentioned, bacterial vaginosis is the most common microbiological disorder affecting the vaginal flora and is often accompanied by pathologic malodorous discharge. However, BV can also be asymptomatic. There are no precise figures on the prevalence of BV in Germany. The reported prevalence in Europe is between 5 and more than $30 \%$ of the population of gynecological patients; the reported incidence in pregnant women is between 7 and 22\% [19]. Previously common terms such as "amine colpitis" or "Gardnerella infection" are misleading with regard to their pathogenetic implications and should not be used. The pathophysiology of the condition has been discussed above.

\section{Clinical importance}

Affected patients are usually prompted to see a doctor because of the unpleasant odor and increased discharge. The odor may only arise intermittently, e.g. after intercourse or during menstruation when vaginal $\mathrm{pH}$ may be elevated due to seminal plasma or blood.

Potentially more serious from a medical point of view is the fact that BV increases the risk for sexually transmitted disease (STD), 
ascending infections from facultative pathogenic vaginal microorganisms and postoperative complications. BV also appears to be a co-factor which enhances the infectiousness of the human immunodeficiency virus (HIV). Seropositive women with BV have been found to have a higher HIV load in genital secretions than women without BV. Other STDs for which BV is a risk factor include chlamydia, trichomoniasis and the herpes simplex virus. $\mathrm{BV}$ can be a predisposing factor in postoperative complications such as vaginal stump infections after hysterectomy as well as infections of the uterus after invasive procedures $[1,8,19,20]$. In pregnant women numerous studies have shown a correlation between $\mathrm{BV}$ and early and late miscarriage, habitual miscarriage, preterm birth, sepsis after miscarriage, and postpartum endometritis. Despite the huge importance of preterm birth for perinatal morbidity and mortality the US recommendations explicitly reject general screening for $\mathrm{BV}$, referring to the currently still inconclusive data [21]. The German guideline points to the positive results reported for screening in the Erfurt and the Thuringian studies on preterm births but also refrains from explicitly coming out in favor of screening. However BV diagnosed during pregnancy is clearly identified as requiring treatment [19].

\section{Diagnosis}

Despite recently emerging knowledge of pathophysiology, a clinical examination as described above is still the gold standard for diagnostic procedures. Microbiological examination is not necessary in normal cases. Diagnosis is based on the four classic criteria developed by Richard Amsel (Amsel criteria), of which at least three must be present [22]:

- pathological discharge

- fishy amine odor (may develop after addition of $\mathrm{KOH}$; so-called whiff test)

- "clue cells" (more than $20 \%$ ) on wet mount

$>\mathrm{pH}>4.5$

Other and additional test methods have been described in the literature, but they are rarely used in Germany or not used at all. Their use is only indicated if microscopy is not available. Complex cases and serious infections can be investigated and scientific studies carried out using Gram stain and the Nugent score as mentioned above. Pap smears are unsuitable for the detection of BV or "Gardnerella infection" [23].

\section{Treatment}

Spontaneous remission of BV has been reported in up to one third of gynecological cases and almost half of obstetric patients [24]. Metronidazole and clindamycin are two equally effective options to treat $\mathrm{BV}$. The international consensus is that both can also be used during pregnancy. However the German guidelines exclude their use in the first trimester of pregnancy although important data on the innocuousness of metronidazole in pregnancy is available for the first trimester of pregnancy [25]. O Table 3 shows a number of treatment options.

Generally accepted indications to treat BV are when patients experience symptoms or if a surgical procedure is planned for the genital area. This applies to both gynecological patients and pregnant women. The majority of experts advise against treating asymptomatic gynecological patients. The rationale for this is the high rates of spontaneous remission and the risk of complications of treatment (e.g. candidiasis). The controversial issue of treating asymptomatic pregnant women has been discussed above (see Clinical Importance).
Table 3 Treatment for bacterial vaginosis (BV). Alternative therapy regimens for bacterial vaginosis (modified after $[1,19,27])$ (selection).

\begin{tabular}{|c|c|c|}
\hline Active ingredient & Dose & Length of treatment \\
\hline Metronidazole & $1 \times 2$ g orally & single dose therapy \\
\hline \multicolumn{3}{|l|}{ Alternatively } \\
\hline Metronidazole & $\times 1 \mathrm{~g}$ & one-day therapy \\
\hline \multicolumn{3}{|l|}{ Alternatively } \\
\hline Metronidazole & $2 \times 500 \mathrm{mg} /$ day orally & 7 days \\
\hline \multicolumn{3}{|l|}{ Alternatively } \\
\hline Metronidazole & $\begin{array}{l}1 \times 100 \mathrm{mg} / \text { day } \\
\text { (vaginal tablet) }\end{array}$ & 6 days \\
\hline \multicolumn{3}{|l|}{ Alternatively } \\
\hline Clindamycin & $\begin{array}{l}1 \times 100 \mathrm{mg} / \text { day } \\
\text { (vaginal cream) }\end{array}$ & 5 days \\
\hline \multicolumn{3}{|c|}{$\begin{array}{l}\text { Meaningful data on the benefits of probiotics is limited and the data is mixed. } \\
\text { Some studies indicate that oral or vaginal administration of lactobacilli [8] } \\
\text { after treatment carried out in accordance with guidelines can prevent recur- } \\
\text { rence (Parma M et al. Probiotics in the prevention of recurrences of bacterial } \\
\text { vaginosis. Altern Ther Health Med } 2014 ; 20 \text { [Suppl. 1]: } 52-57 \text { and Homayouni } \\
\text { A et al. Effects of probiotics on the recurrence of bacterial vaginosis: a review. } \\
\text { J Low Genit Tract Dis } 2014 ; 18: 79-86 B) \text {. Vaginal acidification is sometimes } \\
\text { recommended as offering additional benefits, but the efficacy of this ap- } \\
\text { proach has not been scientifically proven [10]. }\end{array}$} \\
\hline
\end{tabular}

Treating the patient's sexual partner(s) is not recommended. However, direct genital contact should be avoided for the duration of therapy [26].

Patients given metronidazole should abstain from drinking alcoholic beverages because of the risk of disulfiram-like reaction. Clindamycin cream is applied vaginally; it can damage latex condoms for up to five days after treatment has been concluded due to additional substances in the preparation.

Antibiotics should be administered orally during pregnancy. The benefit of oral intake is that it will also target any potential subclinical infection of the upper genital tract [27].

\section{Recurrence}

Recurrence after treatment for BV is a common problem. According to American studies more than $30 \%$ of women initially treated successfully will have recurrence within three months and more than half experience recurrence within one year [28]. A potential cause of recurrence could be that established therapies do not eliminate the bacterial biofilm on the vaginal mucosa [29].

\section{Vulvovaginal Candidiasis}

$\nabla$

\section{Pathogens and prevalence}

Vulvovaginal candidiasis is the second most common cause of the complex of symptoms generally associated with genital infection after bacterial vaginosis. Candida albicans is the cause of candidiasis in more than $90 \%$ of cases. C. glabrata plays the most important role in the remaining $10 \%$; other potential pathogens belong to other species and include C. krusei, C. tropicalis, C. parapsilosis and - very rarely - Saccharomyces cerevisiae [30].

There are many reasons why precise data on the prevalence of this condition is lacking. Many affected women treat the classic symptoms with over-the-counter medicines and only present to a clinic when treatment fails. In addition, doctors often do not obtain a precise diagnosis. It is well known that Candida is only found in around half of cases presenting with itching, discharge, burning sensation and reddening. The often asymptomatic colo- 
Table 4 Therapy for uncomplicated Candida albicans infection. Alternative, equally effective therapy regimens for uncomplicated Candida albicans infection. With the exception of fluconazole and ciclopirox olamine the active agents can also be used during pregnancy although nystatin appears to be less effective in pregnancy. Vaginal therapeutic agents can also be administered in combination with creams; this combination appears to improve treatment outcomes if the vulva is also affected. Based on $[1,12,31]$ (selection).

\begin{tabular}{|c|c|c|}
\hline Active ingredient & Dose & Length of treatment \\
\hline Clotrimazole & $\begin{array}{l}1 \times 500 \mathrm{mg} \\
\text { (vaginal suppository) }\end{array}$ & Single dose therapy \\
\hline \multicolumn{3}{|l|}{ Alternatively } \\
\hline Clotrimazole & $\begin{array}{l}1 \times 200 \mathrm{mg} / \text { day } \\
\text { (vaginal tablets) }\end{array}$ & 3 days \\
\hline \multicolumn{3}{|l|}{ Alternatively } \\
\hline Clotrimazole & $\begin{array}{l}1 \times 100 \mathrm{mg} / \text { day } \\
\text { (vaginal tablets) }\end{array}$ & 6 days \\
\hline \multicolumn{3}{|l|}{ Alternatively } \\
\hline Fluconazole & $1 \times 150 \mathrm{mg}$ orally & Single dose therapy \\
\hline \multicolumn{3}{|l|}{ Alternatively } \\
\hline Ciclopirox olamine & $\begin{array}{l}1 \times 50 \mathrm{mg} / \text { day } \\
\text { (vaginal cream) }\end{array}$ & 6 days \\
\hline \multicolumn{3}{|l|}{ Alternatively } \\
\hline Nystatin & $\begin{array}{l}1 \times 200000 \text { I.E./day } \\
\text { (vaginal suppository) }\end{array}$ & 6 days \\
\hline
\end{tabular}

nization with Candida in sexually mature women (present in around $20 \%$ of non-pregnant women and in more than $30 \%$ of pregnant women) only needs to be treated prepartum to prevent disease of the neonate [31].

\section{Pathogenesis and symptoms}

Vulvovaginal candidiasis has a multifactorial origin. It is assumed that colonization of the estrogenized vagina of sexually mature women occurs through a reservoir in the oro-intestinal tract. The step from asymptomatic colonization to clinically manifest infection depends on the virulence of the yeast and on the patient's disposition. Local defense mechanisms, generally low immunity, gene polymorphisms, poorly controlled diabetes mellitus and antibiotic and estrogen therapies can all play a role. Low-dose combined oral hormonal contraceptives are no longer considered facilitating factors $[1,12,31]$.

All Candida species can cause identical clinical symptoms, although symptoms generated by non-albicans species such as C. glabrata, C. krusei or C. parapsilosis are generally milder. The main symptom is itching, sometimes accompanied by burning sensation, pain, dyspareunia and dysuria. Discharge is typically white, curd-like and largely odorless; the vagina is reddened and edematous. The dermatological categorization of symptoms into eczematous, vesicular and follicular forms of vulval candidiasis indicates just how varied the extravaginal symptoms and manifestations can be [31].

\section{Diagnosis}

Vulvovaginal candidiasis is usually diagnosed with the help of the clinical examinations described above. If a patient presents with the classic symptoms and all other causes have been excluded but neither blastospores nor pseudohyphae are detected on wet mount, samples must be cultured to provide proof of candidiasis [6].

Culturing samples is also necessary if the disease proves to be resistant to therapy or recurs chronically. It is then important to
Table 5 Treatment for chronic recurrent vulvovaginal candidiasis (CRVC). Decreasing-dose maintenance therapy and degressive regimen for CRVC, modified from Donders [36].

\begin{tabular}{|c|c|}
\hline Treatment stage/duration & Medication/dose \\
\hline $\begin{array}{l}\text { Induction } \\
1 \text { week }\end{array}$ & $\begin{array}{l}\text { Fluconazole } 1 \times 200 \mathrm{mg} \text { orally } \\
\text { on days } 1,3 \text { and } 5\end{array}$ \\
\hline $\begin{array}{l}1 \text { st degressive step } \\
8 \text { weeks }\end{array}$ & $\begin{array}{l}\text { Fluconazole } 1 \times 200 \mathrm{mg} \text { orally } \\
1 \times \text { pro week }\end{array}$ \\
\hline $\begin{array}{l}\text { 2nd degressive step } \\
4 \text { months }\end{array}$ & $\begin{array}{l}\text { Fluconazole } 1 \times 200 \mathrm{mg} \text { orally } \\
\text { every } 2 \text { nd week }\end{array}$ \\
\hline $\begin{array}{l}3 \text { rd degressive step } \\
6 \text { months }\end{array}$ & $\begin{array}{l}\text { Fluconazole } 1 \times 200 \mathrm{mg} \text { orally } \\
\text { every month }\end{array}$ \\
\hline \multicolumn{2}{|c|}{$\begin{array}{l}\text { Control examinations should be carried out each month after commencing } \\
\text { degressive treatment. }\end{array}$} \\
\hline \multicolumn{2}{|l|}{ Comments: } \\
\hline \multicolumn{2}{|l|}{$\begin{array}{l}\text { On day } 14 \text { after the start of the in } \\
\text { microscopy and fungal culture. } \\
\text { if results are negative: start 1st } \\
\text { - if results are positive: re-induct }\end{array}$} \\
\hline \multicolumn{2}{|c|}{$\begin{array}{l}\text { if there is clinical recurrence: re-induction, then continue therapy at } \\
\text { previous level }\end{array}$} \\
\hline $\begin{array}{l}\text { If the patient is free of symp } \\
\text { maintain therapy at current }\end{array}$ & copy or culture are positive, \\
\hline
\end{tabular}

find out whether a non-albicans species resistant to the usual antimycotics is present. Chronic recurrent vulvovaginal candidiasis (CRVC) is present if there are four or more incidents of disease per year $[1,6]$.

\section{Treatment}

\section{Uncomplicated Candida albicans infection}

Treatment of uncomplicated, sporadic vulvovaginal Candida albicans infection is not problematic. Treatment can be carried out using any of the approved drugs as indicated; treatment is equally successful with any of them. Available drugs include polyene antifungals (amphotericin B, nystatin), imidazoles (e.g. clotrimazole, ketoconazole, miconazole), triazoles (e.g. fluconazole) and ciclopiroxolamine ( $\bigcirc$ Table 4).

Many women prefer oral single-dose therapy with fluconazole (150 mg). The manufacturer advises against single-dose therapy in pregnancy. However, a large Danish study has confirmed that the standard doses of fluconazole used in gynecology are harmless in the second and third trimester of pregnancy. But the medication should not be taken in the first two months of pregnancy as the study found an increased risk of tetralogy of Fallot [32]. Topical application can be intravaginal (ovules, vaginal tablets) or applied to the vulval area (cream) for 1, 3 or 6 days, depending on the severity of disease and is harmless in pregnancy. Clotrimazole and miconazole have been studied most with regard to their potential teratogenicity [33].

\section{Chronic recurrent vulvovaginal candidiasis (CRVC)}

CRVC poses a therapeutic dilemma. This is also because the causes of this chronic illness with at least four recurrences per year have still not been fully elucidated. Only long-term therapy with stepwise management based on the regimen proposed by Donders offers temporary relief ( $\bullet$ Table 5 ).

In a patient with CRVC the first step must be to investigate again whether treatable risk factors for disease are present (see above). Therapeutic success is unlikely if these risk factors cannot be 
eliminated. Data on whether changes in behavior could help affected individual affected women is contradictory (avoid orogenital sexual contact, not wearing tights, etc.) [34].

By this point at the latest the identification of the yeast type and resistance testing must be carried out. Presence of a very rare infection with C. glabrata or C. krusei could explain a previous failure of treatment. C. krusei ist resistant to fluconazole and therefore needs be treated topically using clotrimazole or ciclopirox olamine for 6-14 days. Another alternative is amphotericin B [31]. Treating $C$. glabrata infection is extremely difficult because the standard treatment regimens often fail (e.g. because of fluconazole resistance), alternative treatments are still poorly investigated, and the drugs used are not always easily available in Germany. However, C. glabrata infection is very rarely symptomatic. Even if $C$. glabrata has been identified as present, a careful differential diagnosis is necessary before attempting treatment. Recommended therapies are fluconazole ( $800 \mathrm{mg}$ per day orally for 2 to 3 weeks) [31] or specially prepared flucytosine vaginal cream ( $5 \mathrm{~g}$ per night for a period 14 days) [35]. However both appear to be losing their efficacy. Off-label use of the very expensive echinocandin micafungin administered i.v. for 15 days has recently been discussed and it is also included in the German guidelines [31].

\section{Trichomoniasis}

$\nabla$

\section{Pathogen and prevalence}

Trichomonas vaginalis, a flagellated protozoan parasite clearly visible on microscopy when motile, is the causative agent of the sexually transmitted disease trichomoniasis. In contrast to other countries, infections in Germany are rare. As trichomoniasis is not a reportable STD, the incidence of diagnosis can only be estimated based on the experiences of large infectiological outpatient clinics.

It is assumed that the parasite is only transmitted sexually. Women are more commonly affected than men. In men, the disease is usually asymptomatic and in the majority of cases affecting men it is self-limiting $[1,12]$.

\section{Symptoms}

As the parasite primarily attacks the squamous epithelium of the urogenital tract, the vagina, cervix, urethra, paraurethral glands and Bartholin glands can be affected. Classic symptoms are malodorous, greenish-yellow discharge, dysuria, dyspareunia and burning sensation in the area of the cervix. Post-coital bleeding has also been reported as an occasional symptom. Depending on the extent of disease, significant signs of inflammation are often found on clinical examination and can include vulval edema and colpitis macularis or "strawberry" cervix caused by punctate hemorrhages.

In addition to the medical conditions caused by the symptoms described above, trichomoniasis is associated with an increased risk for a number of other diseases. These include cervical dysplasias and neoplasias, infertility, preterm birth and HIV infection. In many cases bacterial vaginosis is also present $[1,12]$.

\section{Diagnosis}

In Germany trichomoniasis is usually detected in affected women after a basic infectiological examination as described above. The presence of motile flagellated trichomonads on unstained wet mount is pathognomonic. As the protozoan parasites prefer a
Table 6 Treatment options for trichomoniasis. The most effective treatment and thus the therapy of choice is oral treatment with $2 \mathrm{~g}$ metronidazole which, according to the recommendations of the CDC, can be administered throughout the entire term of pregnancy. German recommendations are more reserved on the use of metronidazole in the first trimester of pregnancy. Nifuratel should not be taken during pregnancy $[1,12,33,37]$.

\begin{tabular}{|c|c|c|}
\hline Active agent & Dose & Length of treatment \\
\hline Metronidazole & $1 \times 2 \mathrm{~g}$ oral & single-dose therapy \\
\hline $\begin{array}{l}\text { Alternatively } \\
\text { Metronidazole }\end{array}$ & $2 \times 1 \mathrm{~g} /$ day orally & one-day therapy \\
\hline $\begin{array}{l}\text { Alternatively } \\
\text { Nifuratel }\end{array}$ & $600 \mathrm{mg} /$ day orally & 10 days \\
\hline $\begin{array}{l}\text { Alternatively } \\
\text { Clotrimazole }\end{array}$ & $\begin{array}{l}1 \times 100 \text { mg/day } \\
\text { (vaginal tablets) }\end{array}$ & $6-10$ days \\
\hline
\end{tabular}

vaginal $\mathrm{pH}$ greater than 4.5 and trichomoniasis is often associated with bacterial vaginosis, additional Amsel criteria are often also present (clue cells, fishy amine odor). The signs of infection (vaginitis, higher number of leukocytes on wet mount) do not correspond to those of BV. Alternatively, trichomoniasis can also be detected on culture or with PCR; the latter investigations are usually reserved for special cases and are carried in special laboratories $[1,12]$.

As with bacterial vaginosis, it is not advisable to uncritically accept findings obtained from fixed Pap stain for the diagnosis of trichomoniasis. In cases with presumed trichomoniasis, clinical examination is always necessary before starting treatment.

As with all STDs, targeted microbiological examinations (culture, molecular or serological investigation) must be done by a specialist laboratory to exclude the presence of other sexually transmitted infections (chlamydia, gonorrhea, syphilis, HIV, hepatitis B and $\mathrm{C}$ ) in patients with trichomoniasis. Cervical cytology must be examined after treatment.

\section{Treatment}

As trichomoniasis is an STD, even asymptomatic infections must be treated and treatment must always include the patient's partner. It is not necessary to confirm the diagnosis of trichomoniasis in a patient's partner before starting treatment. The probability of the partner being infected is high and applies analogously to any concomitant infection with chlamydia or gonorrhea detected at the same time. In the latter cases, the partner should also receive treatment immediately.

Metronidazole is the therapeutic agent of choice to treat trichomoniasis, with oral administration the preferred form of application. Systemic treatment results in higher levels of the active substance in tissue, making it more effective if disease has already reached the urethra, bladder or genital glands [37]. 0 Table 6 lists a number of equivalent regimens. Alternative drugs achieve nowhere near the cure rates obtained with metronidazole or tinidazole (the latter drug is no longer available in Germany). Because of its efficacy, desensitization has been recommended in patients with metronidazole hypersensitivity [38]. Alternatively, patients can be treated with nifuratel or clotrimazole although these drugs are associated with a high rate of recurrence [1].

The advice on metronidazole administration in pregnancy to treat trichomoniasis and the risks of treatment are the same as those described for metronidazole treatment for BV (P. 10). 
Table 7 Differential diagnosis of vulvovaginal symptoms. The parameters listed here can be useful for the rapid diagnosis of vulvovaginal symptoms. It is important to differentiate aerobic vaginitis from atrophic vaginitis. The latter often presents with identical symptoms in women with estrogen deficiency (e.g., postpartum, during the lactation period, in postmenopausal women) and can usually be treated effectively with local application of estriol.

\begin{tabular}{|c|c|c|c|c|}
\hline & Bacterial vaginosis & Vulvovaginal candidiasis & Trichomoniasis & Aerobic vaginitis \\
\hline Medical history & $\begin{array}{l}\text { increased discharge, fishy odor, } \\
\text { no dyspareunia }\end{array}$ & $\begin{array}{l}\text { itching, pain, dyspareunia, } \\
\text { dysuria }\end{array}$ & $\begin{array}{l}\text { dyspareunia, dysuria, } \\
\text { malodorous discharge }\end{array}$ & $\begin{array}{l}\text { dyspareunia, burning } \\
\text { sensation (introitus, vagina) }\end{array}$ \\
\hline Clinical findings & no signs of inflammation & $\begin{array}{l}\text { vaginal erythema or edema; } \\
\text { eczematous, vesicular, follicular } \\
\text { vulva }\end{array}$ & $\begin{array}{l}\text { vulvovaginal erythema, cervical } \\
\text { petechiae ("strawberry" cervix) }\end{array}$ & vaginal inflammation \\
\hline Vaginal discharge & grayish, thin, homogenous & curd-like, white, usually odorless & greenish-yellow, malodorous & $\begin{array}{l}\text { greenish-yellow, } \\
\text { malodorous }\end{array}$ \\
\hline Vaginal pH & higher than 4.5 & lower than 4.5 & higher than 4.5 & higher than 4.5 \\
\hline Wet mount & $\begin{array}{l}\text { mixed bacterial flora, clue cells, } \\
\text { isolated leukocytes }\end{array}$ & $\begin{array}{l}\text { blastospores, pseudohyphae, } \\
\text { lactobacilli, possibly elevated } \\
\text { leukocyte count }\end{array}$ & $\begin{array}{l}\text { trichomonads, clue cells, } \\
\text { elevated leukocyte count }\end{array}$ & $\begin{array}{l}\text { parabasal cells, elevated leu- } \\
\text { kocyte count, no lactobacilli }\end{array}$ \\
\hline $\mathrm{KOH}$ (whiff) test & positive & negative & often positive & negative \\
\hline
\end{tabular}

\section{Aerobic Vaginitis}

$\nabla$

Aerobic vaginitis (AV) is rare and its etiology is still unclear. It is important to differentiate aerobic vaginitis from trichomoniasis as the clinical symptoms are similar; as with trichomoniasis, affected women usually present with greenish-yellow discharge, dyspareunia and burning sensation in the vagina and at the vaginal introitus. Clinical examination signs and symptoms include elevated $\mathrm{pH}$ with extensive inflammation of the vagina, which presents with a striped or patchy reddened appearance [1].

The differential diagnosis will show parabasal cells on wet mount in consequence of the increased desquamation of inflamed vaginal epithelium. Granulocyte count is elevated. The disease is also known as "desquamative inflammatory vaginitis". Trichomonads are not present as the normal lactobacillus-dominated flora is not present. In contrast to BV where the pathogens are primarily anaerobic, aerobic pathogens such as Group B Streptococcus (S. agalactiae) and occasionally Staphylococcus aureus or Escherichia coli predominate in bacterial culture of AV. Atrophic vaginitis must also be considered in the differential diagnosis of AV. However, the importance of these bacteria for pathogenesis is disputed. An immunological inflammatory reaction is currently discussed as most likely cause of AV. Recommendations on the appropriate treatment for AV differ, and the data is unsatisfactory. Mendling references Donders and cites his own experience to recommend a vaginal cream consisting of $1 \%$ hydrocortisone, $0.01 \%$ estriol and $2 \%$ clindamycin (application: half of an applicator administered $2 \times$ per week for a period of four months [1], personally amended). Petersen [14] proposes an initial topical treatment with vaginal clindamycin cream (1× day for one week) complemented by estriol ovules (1-2× per week) and acidification of the vagina using vitamin $\mathrm{C}$.

Symptoms and diagnoses of all diseases discussed here are summarized in $\bullet$ Table 7.

\section{Conclusion}

\section{$\nabla$}

A basic infectiological examination and a good knowledge of the physiology and pathology of vaginal flora will allow the most common causes of uncomplicated vulvovaginal symptoms to be diagnosed and treated without requiring additional microbiological diagnostic procedures (bacterial vaginosis, candidiasis, trichomoniasis). Accidental findings of facultative pathogens on culture in asymptomatic women with intact vaginal flora usually do not require antibiotic treatment. However, any suspicion of severe, recurrent or chronic gynecological infection and - with the exception of trichomoniasis - of any sexually transmitted disease must be examined and treated in accordance with the microbiological and infectiological quality standards of the German Society for Hygiene and Microbiology (DGHM) in cooperation with medical microbiologists.

\section{Conflict of Interest \\ $\nabla$}

None.

\section{References}

1 Mendling W. Gynäkologische Infektionen. Teil 1. Gynäkologe 2012; 45: 959-975

2 Landers DV, Wiesenfeld HC, Heine RP et al. Predictive value of the clinical diagnosis of lower genital tract infection in women. Am J Obstet Gynecol 2004; 190: 1004

3 Mendling W, Mylonas I, Neumann G et al. Mikroskopische Infektionsdiagnostik in der Weiterbildung. Stellungnahme der Arbeitsgemeinschaft für Infektionen und Infektionsimmunologie (AGII)/189. Stellungnahme der DGGG. Frauenarzt 2014; 55: 663-665

4 Mashburn J. Vaginal infections update. J Midwifery Womens Health 2012; 57: 629-634

5 Sobel JD. Vulvovaginitis in healthy women. Compr Ther 1999; 25: 335346

6 Podbielski A, Herrmann M, Kniehl E et al., Hrsg. Mikrobiologisch-infektiologische Qualitätsstandards (MiQ) 10. Genitalinfektionen Teil I. Infektionen des weiblichen und des männlichen Genitaltraktes. 2. Aufl. München: Urban \& Fischer; 2011

7 Podbielski A, Mauch H, Kniehl E et al., Hrsg. Mikrobiologisch-infektiologische Qualitätsstandards (MiQ) 11a. Genitalinfektionen Teil II. Infektionserreger: Bakterien. 2. Aufl. München: Urban \& Fischer; 2011

8 Lamont RF, Sobel JD, Akins RA et al. The vaginal microbiome: new information about genital tract flora using molecular based techniques. BJOG 2011; 118: 533-549

9 Witkin SS, Linhares I, Giraldo P et al. An altered immunity hypothesis for the development of symptomatic bacterial vaginosis. Clin Infec Diseases 2007; 44: 554-557

10 Hyman RW, Fukushima M, Diamond L et al. Microbes on the human vaginal epithelium. Proc Natl Acad Sci U S A 2005; 102: 7952-7957

11 Senok AC, Verstraelen $H$, Temmerman $M$ et al. Probiotics for the treatment of bacterial vaginosis. Cochrane Database Syst Rev 2009; 4: CD006289

12 Arbeitsgemeinschaft für Infektiologie und Infektionsimmunologie (AGII) der DGGG. Expertenkommission „Vaginale Infektionen“ der AIG. Praktisches Vorgehen bei bakterieller Vaginose, Vulvovaginalkandidose und Trichomoniasis. Frauenarzt 2013; 54: 828-837 
13 Romosan G, Valentin L. The sensitivity and specificity of transvaginal ultrasound with regard to acute pelvic inflammatory disease: a review of the literature. Arch Gynecol Obstet 2014; 289: 705-714

14 Petersen EE. Infektionen in Gynäkologie und Geburtshilfe. Lehrbuch und Atlas. 5., neu bearbeitete und erweiterte Aufl. Stuttgart: Thieme; 2011

15 Neumann G, Schäfer A, Mendling W. Phasenkontrast-Mikroskopie in der Frauenarztpraxis. Berlin, Heidelberg: Springer; 2014

16 CDC. Pelvic inflammatory disease. Online: http://www.cdc.gov/std/ treatment/2010/pid.htm; last access: 31.07.2014

17 Mendling W. Gynäkologische Infektionen. Teil 2: Zervizitis, Salpingitis und Herpes genitalis. Gynäkologe 2013; 46: 117-128

18 Ross J, Judlin P. European Guideline for the management of pelvic inflammatory disease. June 2012, proposed date for review: June 2015. Online: http://www.iusti.org/regions/europe/pdf/2012/PID_Treatment_Guidelines-Europe2012v5.pdf; last access: 31.07.2014

19 Mendling W, Hrsg. S1-Leitlinie AWMF-Register-Nr. 015/028. Bakterielle Vaginose (BV) in Gynäkologie und Geburtshilfe. Gültig bis 31.08.2016. Online: http://www.awmf.org/leitlinien/detail/1//015-028.html

20 Soper DE. Bacterial vaginosis and postoperative infections. Am J Obstet Gynecol 1993; 169: 467-469

21 U.S. Preventive Services Task Force. Screening for bacterial vaginosis in pregnancy to prevent preterm delivery: recommendation statement. Ann Intern Med 2008; 148: 214-219

22 Amsel R, Trotten PA, Spiegel CA et al. Nonspecific vaginitis. Diagnostic criteria and microbial and epidemiologic associations. Am J Med 1983; 74: 14-22

23 Greene JF 3rd, Kuehl TJ, Allen SR. The papanicolaou smear: inadequate screening test for bacterial vaginosis during pregnancy. Am J Obstet Gynecol 2000; 182: 1048

24 Klebanoff MA, Hauth JC, MacPherson CA et al. Time course of the regression of asymptomatic bacterial vaginosis in pregnancy with and without treatment. Am J Obstet Gynecol 2004; 190: 363-370

25 Burtin P, Taddio A, Ariburnu $O$ et al. Safety of metronidazole in pregnancy: a meta-analysis. Am J Obstet Gynecol 1995; 172: 525-529

26 Bradshaw CS, Vodstrcil LA, Hocking JS et al. Recurrence of bacterial vaginosis is significantly associated with posttreatment sexual activities and hormonal contraceptive use. Clin Infect Dis 2013; 56: 777

27 Centers for Disease Control and Prevention. Bacterial vaginosis. Treatment. Online: http://www.cdc.gov/std/treatment/2010/vaginal-discharge.htm; last access: 31.07.2014
28 Bradshaw CS, Morton AN, Hocking J et al. High recurrence rates of bacterial vaginosis over the course of 12 months after oral metronidazole therapy and factors associated with recurrence. J Infect Dis 2006; 193: 1478

29 Swidsinski A, Mendling W, Loening-Baucke $V$ et al. An adherent Gardnerella vaginalis biofilm persists on the vaginal epithelium after standard therapy with oral metronidazole. Am J Obstet Gynecol 2008; 198: 97.e1-97.e6

30 Mendling $W$. Vaginose, Vaginitis, Zervizitis und Salpingitis. 2., erweiterte und vollständig neu bearbeitete Aufl. Heidelberg: Springer; 2006

31 Mendling W, Hrsg. S-2 K Leitlinie AWMF-Register-Nr. 015/072.Vulvovaginalkandidose. Gültig bis 31.12.2016. Online: http://www.awmf.org/ leitlinien/detail/11/015-072.html

32 Mølgaard-Nielsen D, Pasternak B, Hviid A. Use of oral fluconazole during pregnancy and the risk of birth defects. NEJM 2013; 369: 830-839

33 Schaefer C, Spielmann H, Vetter $K$ et al., Hrsg. Arzneimittel in Schwangerschaft und Stillzeit. 8. Aufl. München: Urban \& Fischer; 2012

34 Patel DA, Gillespie B, Sobel JD et al. Risk factors for recurrent vulvovaginal candidiasis in women receiving maintenance antifungal therapy: results of a prospective cohort study. Am J Obstet Gynecol 2004; 190: 644

35 Sobel JD, Chaim W, Nagappan V et al. Treatment of vaginitis caused by Candida glabrata: use of topical boric acid and flucytosine. Am J Obstet Gynecol 2003; 189: 1297

36 Donders G, Bellen G, Byttebier $G$ et al. Individualized decreasing-dose maintenance fluconazole regimen for recurrent vulvovaginal candidiasis (ReCiDiF trial). Am J Obstet Gynecol 2008; 199: 613.e1-613.e9

37 CDC. Trichomoniasis. Treatment. Online: http://www.cdc.gov/std/ treatment/2010/vaginal-discharge.htm; last access: 31.07.2014

38 Helms DJ, Mosure DJ, Secor WE et al. Management of trichomonas vaginalis in women with suspected metronidazole hypersensitivity. Am J Obstet Gynecol 2008; 198: 370.e1

39 Michigan Regional Laboratory Wet Mount Proficiency Program. Online: http://www.michigan.gov/mdch/0,4612,7-132-2945_5103_ 7168-74548-,00.html; last access: 31.07.2014

40 Bevan $C D$, Ridgway GL, Rothermel $C D$. Efficacy and safety of azithromycin as monotherapy or combined with metronidazole compared with two standard multidrug regimens for the treatment of acute pelvic inflammatory disease. J Int Med Res 2003; 31: 45-54 